\title{
In situ study of the effect of Nitrate on the Electrochemical migration of Tin under Chloride- containing Thin Electrolyte Layer
}

\author{
Bokai Liao', Zhenyu Chen ${ }^{1,2 *}$ and Xingpeng Guo ${ }^{1,2}$ \\ ${ }^{1}$ Key Laboratory for Material Chemistry of Energy Conversion and Storage, Ministry of Education, School of Chemistry and Chemical \\ Engineering, Huazhong University of Science and Technology Wuhan 430074, China \\ ${ }^{2}$ Hubei Key Laboratory of Materials Chemistry and Service Failure, School of Chemistry and Chemical Engineering, Huazhong \\ University of Science and Technology, Wuhan 430074, China
}

\section{Article Info}

\section{*Corresponding author:}

\section{Zhenyu Chen}

Key Laboratory for Material Chemistry of Energy Conversion and Storage

Ministry of Education, School of Chemistry and Chemical Engineering

Huazhong University of Science and

Technology Wuhan 430074

China

Tel: +86-27-87543432

Fax: +86-27-87543632

Email: chenzhenyu@mail.hust.edu.cn

Received: September 14, 2016

Accepted: September 22, 2016

Published: September 25, 2016

Citation: Liao B, Chen Z, Guo X. In situ study of the effect of Nitrate on the Electrochemical migration of Tin under Chloride-containing Thin Electrolyte Layer. Madridge J Anal Sci Instrum. 2016; 1(1): 4-10.

doi: 10.18689/mjai-1000102

Copyright: @ 2016 The Author(s). This work is licensed under a Creative Commons Attribution 4.0 International License, which permits unrestricted use, distribution, and reproduction in any medium, provided the original work is properly cited.

Published by Madridge Publishers

\begin{abstract}
The effect of nitrate on the electrochemical migration (ECM) of tin under thin electrolyte layers (TELs) containing chloride ions was studied by in situ electrochemical measurements and optical observation coupled with ex situ characterization. The longest time to bridge electrodes in the TELs was achieved at medium nitrate concentration despite the general trend to decrease with increasing pollutant concentration. Mechanisms have been proposed to explain the ECM of tin in the TELs with various nitrate concentrations.
\end{abstract}

Keywords: Electrochemical Migration; Dendrite Growth; Tin; Nitrate; Thin Electrolyte Layer.

\section{Introduction}

Electrochemical migration (ECM), which is a form of corrosion, significantly compromises the corrosion reliability of electronic devices [1-3]. This process occurs when two oppositely biased and closely spaced electrodes are connected by an aqueous electrolyte and results in the growth of metallic dendrites between electronic components to form short circuits. ECM has become a severe reliability issue in the electronic industry because of the miniaturization of electronic devices and their increasing sensitivity to contaminations $[4,5]$.

Currently, lead-free tin-based solders, which commonly consist of almost $95 \%$ tin, are widely used for surface finish on printed circuit board assemblies or other electronic packages [6]. Given their significant roles in electronic devices, tin and its alloys have been extensively studied for their ECM. In particular, previous studies focused on ECM test methods [7,8], ECM influencing factors (alloy elements [9-12], solution chemistry [13-15], steady and unsteady state electric fields $[16,17])$, tin dendrite morphology $[18,20]$, and ECM mechanism $[1,3]$.

Considering the deteriorating environments of the storage and usage of electronic devices, previous works have proven that the common pollutant chloride plays an important role in ECM $[14,21,22]$. However, few reports focused on the effect of nitrate ion, another significant contaminant produced from human and natural activities, on the ECM of tin [23-25]. Furthermore, nitrate plays an increasing role in the environment because of its elevated concentration derived from anthropogenic excess input, such as coal combustion and vehicle emission [26]. 
In the present study, we investigated the effect of nitrate on the ECM behavior of tin under TELs containing chloride ions by using in situ electrochemical and optical techniques that have been employed in our previous work [22]. The morphology and composition of products generated after ECM were analyzed using field emission-scanning electron microscopy (FE-SEM) with energy dispersive spectroscopy (EDS) and X-ray diffraction (XRD). The effect of nitrate concentration on the ECM behaviour of tin was also investigated, and the mechanisms involved were discussed in detail.

\section{Experimental}

\section{Materials and setup for the TEL test}

Pure tin (>99.999 wt.\%) with dimensions of $2 \mathrm{~mm} \times 5 \mathrm{~mm}$ $\times 10 \mathrm{~mm}$ was used in this experiment. Two identical tin electrodes (working area of $0.1 \mathrm{~cm}^{2}$ ), i.e., a working electrode (WE) as cathode and a counter electrode (CE) as anode, were embedded in an epoxy resin cylinder with a gap size of 0.5 $\mathrm{mm}$ in parallel direction. A copper wire was welded to the backside of each electrode to ensure the electric connection. Before each test, the electrode surface was ground to 1200 grit with a silicon carbide paper. The surface was rinsed with deionized water, degreased with acetone, and then dried in cool air.

The ECM cell set-up and TEL test were performed as previously described [22]. Sodium nitrate solution (1-100 $\mathrm{mM}$ ) and $\mathrm{NaCl}$ solution (1 $\mathrm{mM}$ ) were prepared with deionized water (18.2 $\mathrm{M} \Omega$ in resistivity) and analytical grade reagents. Solution conductivity was tested by a JENCO Model 3173 conductivity tester. Direct current bias voltage $(5 \mathrm{~V})$ was applied between the two tin electrodes, and the current flowing through the two electrodes was recorded simultaneously as a function of time. During the ECM test, morphologies of dendrite and the electrode surface were in situ recorded employing a VHX-1000E digital 3D microscope (Keyence, Japan) at different time intervals. During the experiment, the ECM cell was covered with a glass lid to minimize the evaporation of the TEL. To verify reproducibility, all ECM measurements were repeated at least five times.

\section{Cyclic voltammetry (CV) measurement}

$\mathrm{CV}$ measurement was performed with a conventional three-electrode system in a single compartment cell at room temperature. The counter and reference electrodes were a large Pt foil $\left(1 \mathrm{~cm}^{2}\right)$ and a saturated calomel electrode (SCE), respectively. The working electrode used was pure tin $(0.75$ $\mathrm{cm}^{2}$ ) sealed by epoxy resins, and surface preparation was the same as that in the ECM test. The CV measurement was performed in the potential range from $-2.5 \mathrm{~V}$ to $-0.7 \mathrm{~V}$ (versus $\mathrm{SCE}$ ) at a scan rate of $30 \mathrm{mV} / \mathrm{s}$, starting from $-1.8 \mathrm{~V}$ (versus $\mathrm{SCE}$ ), and 10 cycles were recorded. Before the test, the working electrode was polarized at $-1.8 \mathrm{~V}$ (versus SCE) for $15 \mathrm{~min}$.

\section{Ex situ characterization of dendrites and precipitates}

After the ECM test, the samples were dried in nitrogen gas at room temperature. The surface morphologies were examined by FE-SEM (Phillips Quanta 200, America) coupled to an EDS. XRD analysis for the composition of products was carried out using a PANalytical B.V. X-ray diffractometer (model X'Pert PRO) with $\mathrm{Cu} K \alpha$ radiation $(\lambda=0.15604 \mathrm{~nm})$. The diffractograms were obtained in the $2 \theta$ range of $10^{\circ}-90^{\circ}$ using a $0.02^{\circ}$ step and acquisition time of $2 \mathrm{~s} /$ step.

\section{Results}

\section{Current density vs. time curves and mean time to short circuit from the ECM test}

Typical current density versus time curves during the ECM test of tin in $200 \mu \mathrm{m}$-thick electrolyte layers with $1 \mathrm{mM} \mathrm{Cl}$-and various nitrate concentrations at $5 \mathrm{~V}$ are shown in Fig. 1. The initial current density increased with increasing nitrate concentration. Sudden current density spikes appeared at all test concentrations, indicating that the formed conductive dendrites bridged the two electrodes and resulted in short circuit. Figure 2 shows the mean time to short circuit recorded from the ECM tests as a function of nitrate concentration. In general, ECM becomes more susceptible with an increase in pollutant concentration [27]. However, failure time increased sharply when the nitrate concentration was increased from 10 $\mathrm{mM}$ to $50 \mathrm{mM}$ but fluctuated at about $20 \mathrm{~s}$ with low nitrate concentrations (1-5 mM). Moreover, failure time decreased from $1617 \mathrm{~s}$ to $81 \mathrm{~s}$ at $100 \mathrm{mM}$ nitrate and then further decreased to $16 \mathrm{~s}$ at $200 \mathrm{mM}$ nitrate. This result suggests that the slowest growth rate of dendrites was achieved at medium nitrate concentrations.

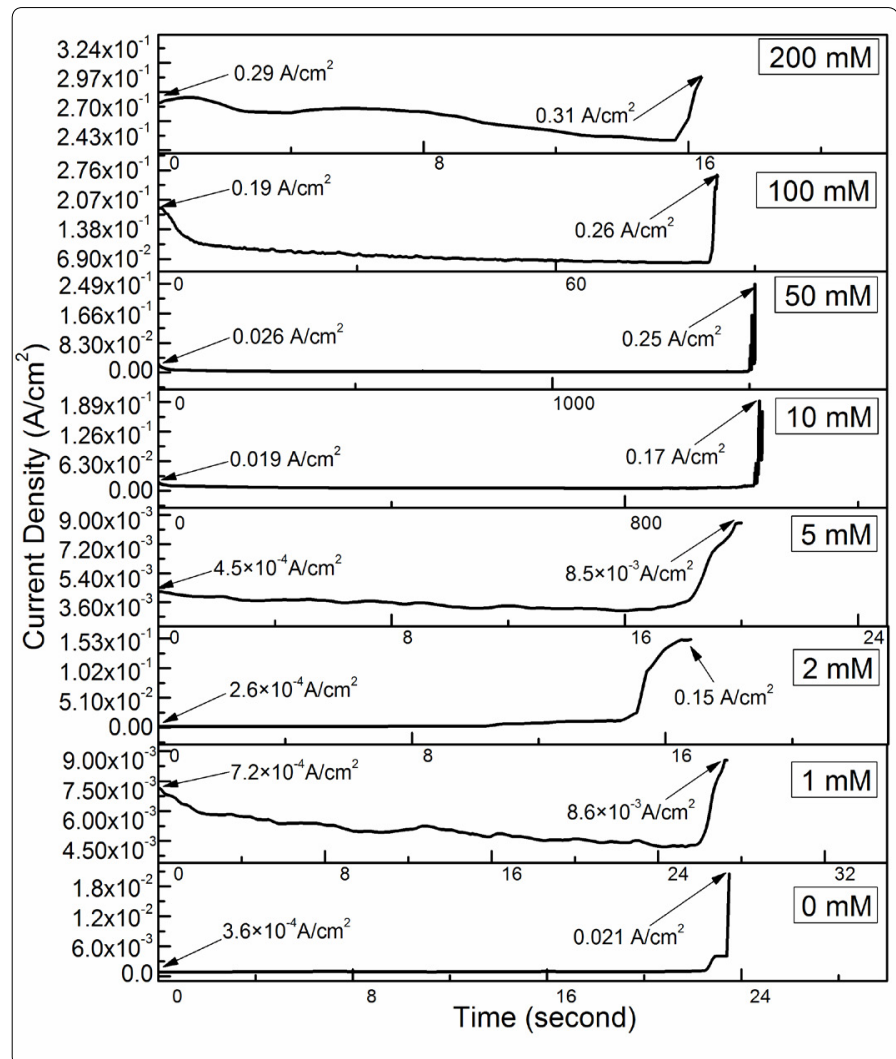

Fig. 1. Typical current density vs. time curves for the ECM of tin in $200-\mu \mathrm{m}$-thick electrolyte layers containing various concentrations of nitrate and $1 \mathrm{mM} \mathrm{Cl}$ - at bias voltage $5 \mathrm{~V}$. 


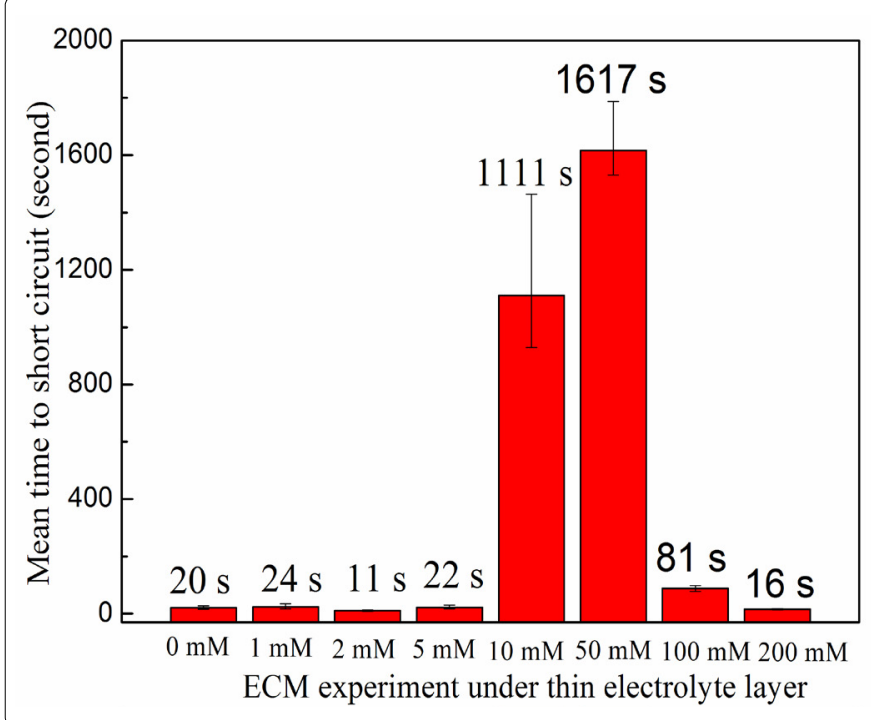

Fig. 2. Effect of nitrate concentration on the mean time to short circuit of two tin electrodes in 200- $\mu$ m-thick electrolyte layers at bias voltage $5 \mathrm{~V}$

\section{In situ real-time observation of ECM development}

Figs. 3 and 4 show in situ optical micrographs of the ECM of tin in $200 \mu \mathrm{m}$-thick electrolyte layers containing $1 \mathrm{mM} \mathrm{Cl}-$ and different nitrate concentrations at $5 \mathrm{~V}$ at different time points. The amounts of precipitates and bubbles increased with increasing nitrate concentration at the initial time. A thick precipitate layer formed near the anode side rather than the area between the anode and the cathode at the end of ECM. This result can be attributed to the much faster migration rate of $\mathrm{OH}^{-}$than those of $\mathrm{Sn}^{4+}$ and $\mathrm{Sn}^{2+}$ caused by the strong convection effect resulting from bubbles escaping from the cathode [22]. As shown in Figs. $4 a-4 d$, the number of tree- or needle-like dendrites increased with increasing nitrate concentrations.
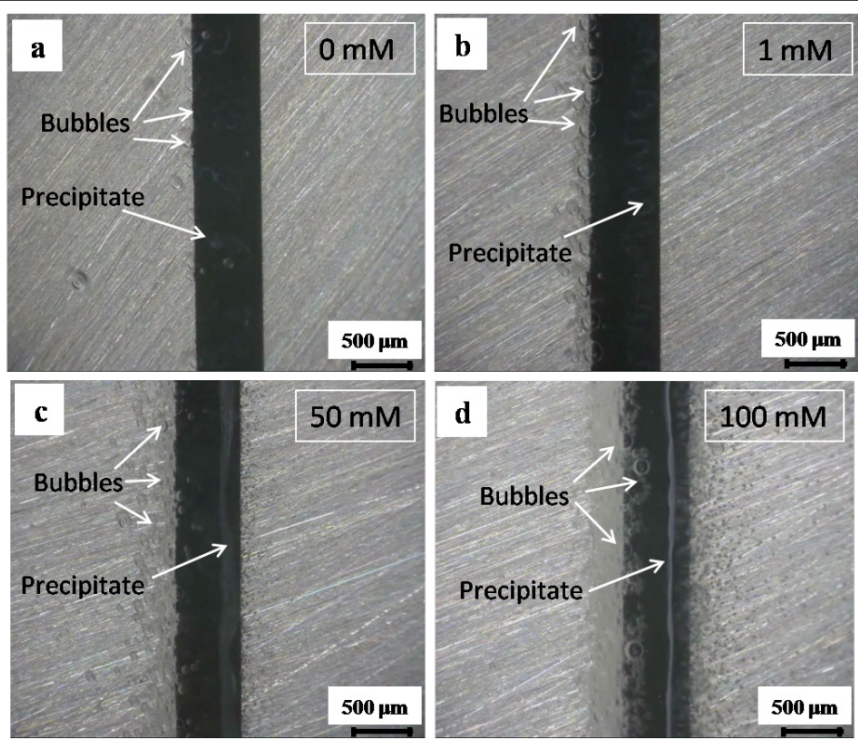

Fig. 3. In situ optical micrographs of electrochemical migration of tin in 200- $\mu$ m-thick electrolyte layer containing $1 \mathrm{mM} \mathrm{Cl}-$ and varied nitrate concentrations with bias voltage of $5 \mathrm{~V}$ at $2 \mathrm{~s}$ : (a) $0 \mathrm{mM}$, (b) $1 \mathrm{mM}$, (c) $50 \mathrm{mM}$,

(d) $100 \mathrm{mM}$ (anode is on the right and cathode is on the left).

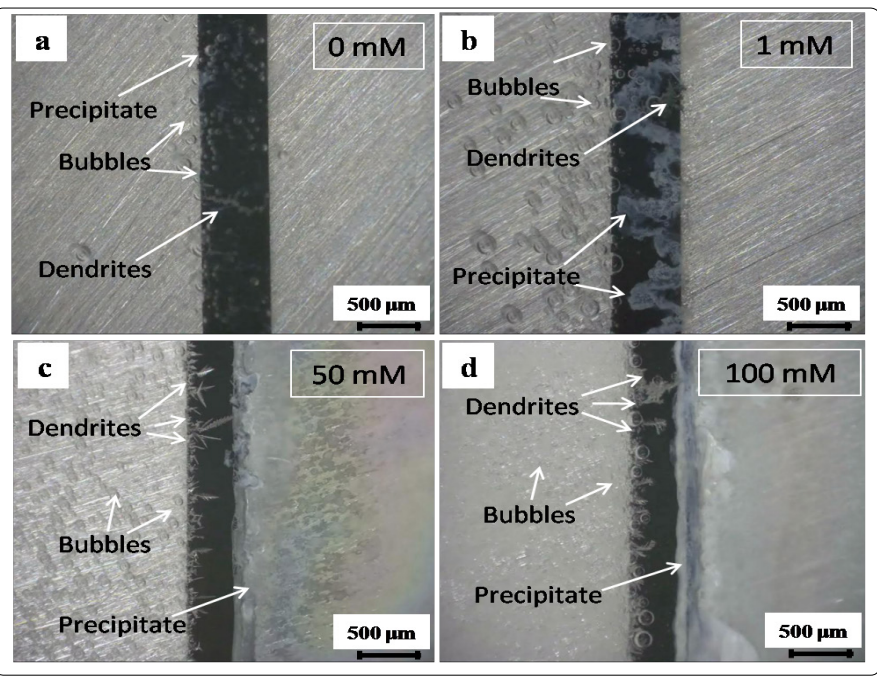

Fig. 4. In situ optical micrographs of electrochemical migration of tin in 200- $\mu \mathrm{m}$-thick electrolyte layer containing $1 \mathrm{mM} \mathrm{Cl}$ - and varied nitrate concentrations with bias voltage of $5 \mathrm{~V}$ within different time intervals: (a) $0 \mathrm{mM}, 20 \mathrm{~s}$; (b) $1 \mathrm{mM}, 24 \mathrm{~s}$; (c) $50 \mathrm{mM}, 1617 \mathrm{~s}$; (d) 100

$\mathrm{mM}, 81 \mathrm{~s}$ (anode is on the right and cathode is on the left).

\section{Real-time $\mathrm{pH}$ distribution on the electrode surface during ECM}

Local $\mathrm{pH}$ development was visualized by adding a universal $\mathrm{pH}$ indicator $(\mathrm{pH} 1-14)$ to the $200 \mu \mathrm{m}$-thick electrolyte layer to understand the local $\mathrm{pH}$ distribution on both electrodes during the ECM test. Fig. 5 shows the in situ visual evidence of the $\mathrm{pH}$ distribution change with time in $1 \mathrm{mM} \mathrm{Cl}-$ and varied nitrate concentrations at 5 V. Prior to applying bias voltage, the $\mathrm{pH}$ was between 6 and 7 . Upon voltage application, the electrolyte on the cathode part turned alkaline (blue/purple in color), whereas that on the anode part became acidic (red in color) within $2 \mathrm{~s}$. The $\mathrm{pH}$ of the cathode area increased with time, whereas that of the anode area decreased with time. The amount of bubbles increased on the cathode side, and change in $\mathrm{pH}$ became faster as the nitrate concentration was increased. The alkaline region (blue/purple in color) diffused quickly to the anode side with time because of the increasing $\mathrm{OH}^{-}$ concentration and strong convection effect caused by the evacuation of bubbles on the cathode surface. Furthermore, the alkaline region diffused faster in $50 \mathrm{mM}$ than $200 \mathrm{mM}$ nitrate in $10 \mathrm{~s}$. This finding could be attributed to the hindering effect of the thicker precipitate layer in $200 \mathrm{mM}$ nitrate, which slowed the migration of $\mathrm{OH}^{-}$.

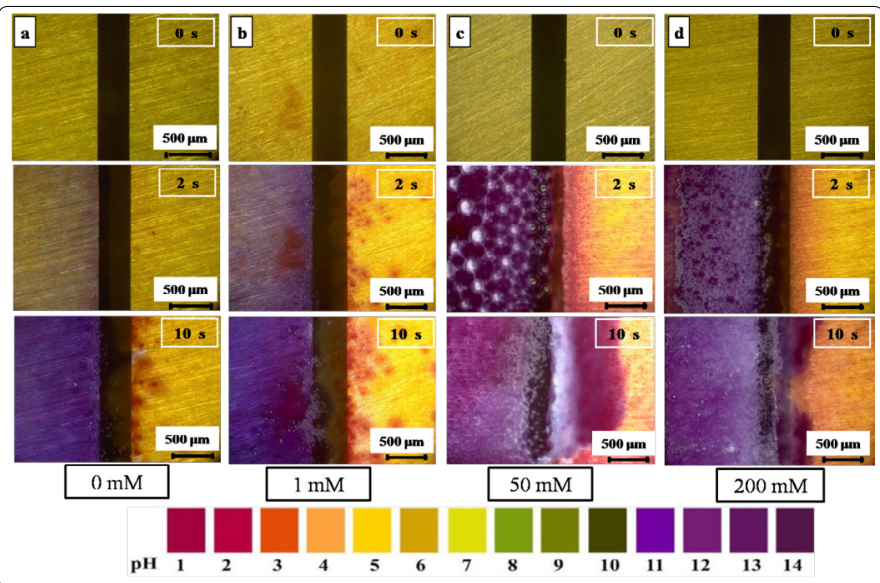

Fig. 5. Visualization of localized $\mathrm{pH}$ distribution on the both electrodes using $\mathrm{pH}$ indicator in 200- $\mu \mathrm{m}$-thick electrolyte layers containing $1 \mathrm{mM}$ $\mathrm{Cl}$ and varied concentrations of nitrate ion at $5 \mathrm{~V}$ within different time intervals (anode is on the right and cathode is on the left). 


\section{Ex situ characterization of dendrites and precipitates}

The microstructure and composition of the products generated after ECM were characterized using SEM, EDS, and XRD. Fig. 6 shows the SEM images of the samples after ECM tests with various nitrate concentrations at $5 \mathrm{~V}$. Tree- and needle-like dendrites formed after all the ECM tests, but the branches of the dendrites became coarser in the presence of various nitrate concentrations. The composition of products generated after ECM was determined by EDS and XRD. Fig. 7a shows the typical XRD peaks of $\mathrm{Sn}, \mathrm{SnO}$, and $\mathrm{SnO}_{2}$, and the blunt peak is attributed to the peak of epoxy resin base. Therefore, the products generated from the ECM test were mainly composed of stannic hydroxide/oxide and stannous hydroxide/oxide. Moreover, the EDS data of the dendrites produced after ECM in the presence of $100 \mathrm{mM}$ nitrate at $5 \mathrm{~V}$ for $81 \mathrm{~s}$ is shown in Fig. 7b. The dendrites consisted mainly of tin, which agrees with the results of a previous study [20].
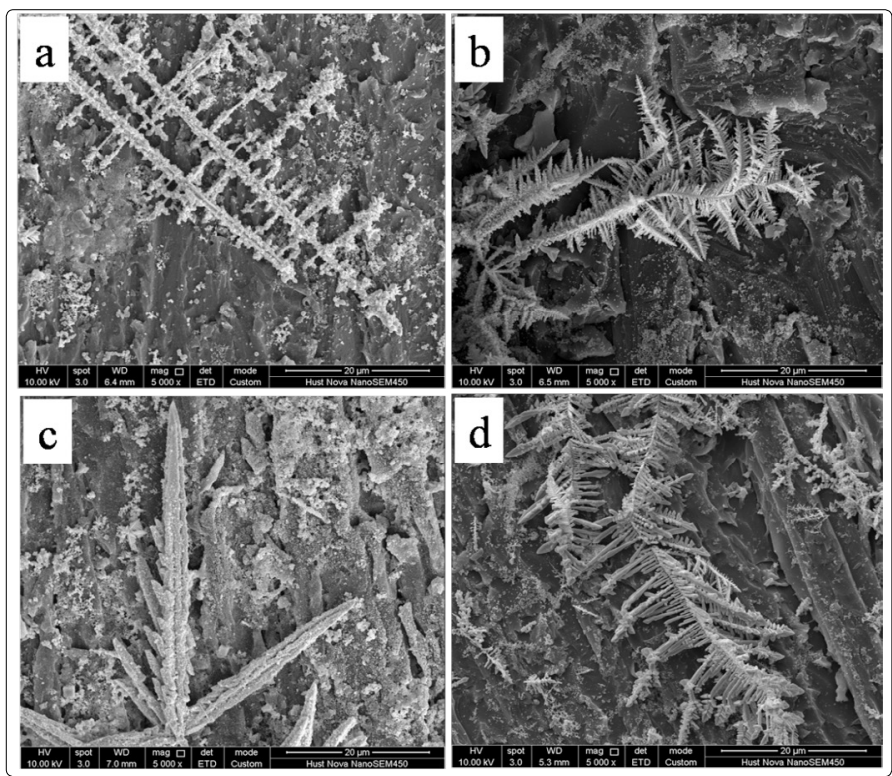

Fig. 6. SEM images of dendrites formed during the ECM of tin in $200-\mu \mathrm{m}$-thick electrolyte layers containing $1 \mathrm{mM} \mathrm{Cl}^{-}$and varied concentrations of nitrate ion at $5 \mathrm{~V}$ within different time intervals: (a) $0 \mathrm{mM}, 20 \mathrm{~s}$; (b) $1 \mathrm{mM}, 24 \mathrm{~s}$; (c) $50 \mathrm{mM}, 1617 \mathrm{~s}$;

(d) $100 \mathrm{mM}, 81 \mathrm{~s}$ (obtained between the two electrodes).

\section{Discussion}

\section{Basic reactions involved in the ECM of tin}

According to our previous work $[16,21]$, the main anodic reactions for tin in TELs containing $1 \mathrm{mM} \mathrm{Cl}$-are as follows:

$$
\begin{aligned}
& \mathrm{Sn} \rightarrow \mathrm{Sn}^{2+}+2 \mathrm{e}^{-} \\
& \mathrm{Sn}^{2+} \rightarrow \mathrm{Sn}^{4+}+2 \mathrm{e}^{-} \\
& 2 \mathrm{H}_{2} \mathrm{O} \rightarrow 4 \mathrm{H}^{+}+\mathrm{O}_{2}+4 \mathrm{e}^{-} \\
& 2 \mathrm{Cl}^{-} \rightarrow \mathrm{Cl}_{2}+2 \mathrm{e}^{-} .
\end{aligned}
$$

Before the generation of dendrites, the main cathodic reactions may only include the reduction of water (Reaction (5)) and dissolved $\mathrm{O}_{2}$ (Reaction (6)):

$$
\begin{aligned}
& 2 \mathrm{H}_{2} \mathrm{O}+2 \mathrm{e}^{-} \rightarrow \mathrm{H}_{2}+2 \mathrm{OH}^{-} \\
& \mathrm{O}_{2}+2 \mathrm{H}_{2} \mathrm{O}+4 \mathrm{e}^{-} \rightarrow 4 \mathrm{OH}^{-}
\end{aligned}
$$
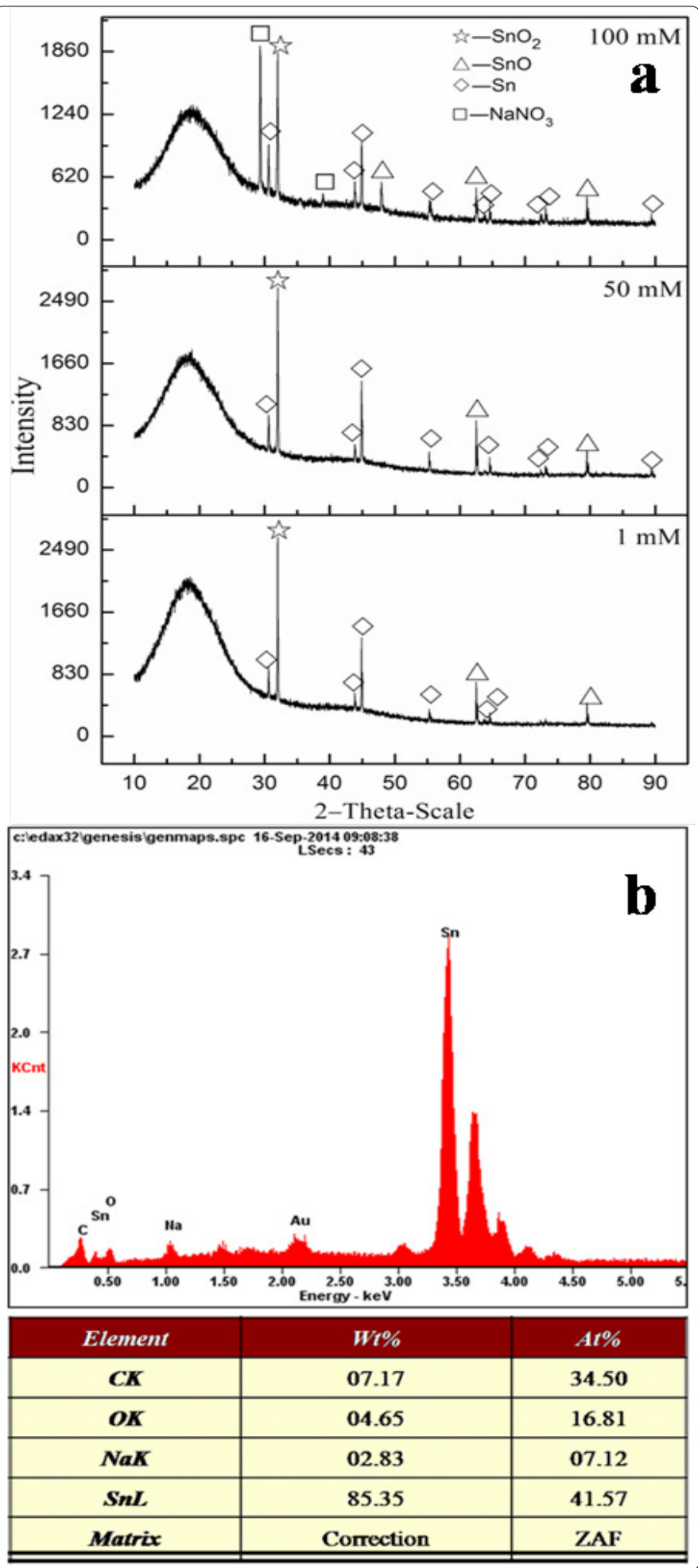

Fig. 7. Composition analysis of (a) XRD peaks of products formed during the ECM in 200- $\mu$ m-thick electrolyte layers containing $1 \mathrm{mM}$

$\mathrm{Cl}-$ and varied nitrate concentrations and (b) EDS pattern of dendrites formed during the ECM of tin in 200- $\mu$ m-thick electrolyte layers containing $1 \mathrm{mM} \mathrm{Cl}^{-}$and $100 \mathrm{mM}$ nitrate ion at $5 \mathrm{~V}$ for $81 \mathrm{~s}$.

When these ions come in contact during the migration, the dominant precipitate $\mathrm{Sn}(\mathrm{OH})_{4}$ will be formed easily because of its low solubility (solubility product constant $\mathrm{Ksp}=$ 10-56, at $298.15 \mathrm{~K}$ ) as shown in Reaction (7). $\mathrm{Sn}(\mathrm{OH})_{4}$ will be dissolved to form $\left[\mathrm{Sn}(\mathrm{OH})_{6}\right]^{2-}$ under high $\mathrm{OH}$ - concentrations (Reaction (8)). The growth of dendrites can be attributed to the reduction of $\mathrm{Sn}^{2+}, \mathrm{Sn}^{4+}$, and/or $\left[\mathrm{Sn}(\mathrm{OH})_{6}\right]^{2-}$.

$$
\mathrm{Sn}^{4+}+4 \mathrm{OH}^{-} \rightarrow \mathrm{Sn}(\mathrm{OH})_{4}
$$




$$
\begin{aligned}
& \mathrm{Sn}(\mathrm{OH})_{4}+2 \mathrm{OH}^{-} \rightarrow \mathrm{Sn}(\mathrm{OH})_{6}^{2-} \\
& \mathrm{Sn}^{2+}+2 \mathrm{e}^{-} \rightarrow \mathrm{Sn} \\
& \mathrm{Sn}^{4+}+4 \mathrm{e}^{-} \rightarrow \mathrm{Sn} \\
& {\left[\mathrm{Sn}(\mathrm{OH})_{6}\right]^{2-}+4 \mathrm{e}^{-} \rightarrow \mathrm{Sn}+6 \mathrm{OH}^{-}}
\end{aligned}
$$

\section{Effect of nitrate ion on the ECM behavior of tin}

I. Katsounaros et al. [28] found that electrochemical reduction of nitrate ion might occur on tin electrode at high cathodic potentials. However, the mechanism of nitrate reduction is complicated because of its multi-electron nature and the presence of a large number of intermediates $[29,30]$. Nitrogen and/or ammonium are the main reaction products in alkaline medium [31,32]. A consecutive reaction mechanism can describe the reduction process as Reactions (12)-(14) [28,33]:

$$
\begin{aligned}
& \mathrm{NO}_{3}{ }^{-}+\mathrm{H}_{2} \mathrm{O}+2 \mathrm{e}^{-} \rightarrow \mathrm{NO}_{2}{ }^{-}+2 \mathrm{OH}^{-}(\mathrm{E} 0=0.01 \mathrm{~V} . \mathrm{SHE}) \\
& \mathrm{NO}_{2}{ }^{-}+5 \mathrm{H}_{2} \mathrm{O}+6 \mathrm{e}^{-} \rightarrow \mathrm{NH}_{3}+7 \mathrm{OH}^{-}\left(\mathrm{E}^{0}=-0.165 \mathrm{~V} . \mathrm{SHE}\right) \\
& \left.2 \mathrm{NO}_{2}{ }^{-}+4 \mathrm{H}_{2} \mathrm{O}+6 \mathrm{e}^{-} \rightarrow \mathrm{N}_{2}+8 \mathrm{OH}^{-} \text {(EO }=0.406 \mathrm{~V} . \mathrm{SHE}\right) .
\end{aligned}
$$

After the ECM test, the electrolyte was analyzed with through ion chromatography (Metrohm 881 Compact IC Pro, Switzerland). The electrolyte contained $12.62 \mathrm{mM}$ ammonium in the presence of $200 \mathrm{mM}$ nitrate at a bias voltage of $5 \mathrm{~V}$ after $16 \mathrm{~s}$. Nitrogen may be the main product in the test condition. Tucker et al. [34] reported that nitrogen is main reaction product of nitrate reduction on activated rhodium electrode in alkaline solution.

Moreover, CV measurement was performed to account for the effect of nitrate on the ECM of tin. Fig. 8 shows cyclic voltammograms of $S n$ electrode in solutions containing $1 \mathrm{mM}$ $\mathrm{NaCl}$ and various nitrate concentrations. The peaks were attributed to the oxidation/reduction of $\mathrm{Sn}^{2+}$ to $\mathrm{Sn}^{4+}\left(\mathrm{SnO}_{2}\right.$ and/or $\left.\mathrm{Sn}(\mathrm{OH})_{4}\right)$ species. The increase of the peak current in the presence of nitrate is attributed to the increased corrosion of tin because nitrate ion can be reduced to facilitate the cathodic reaction [35]. However, whether the increase in current density was mainly due to the nitrate reduction reaction or the hydrogen evolution reaction that was enhanced by the increase in ionic intensity remains to be clarified. Thus, CV measurement was carried out in solutions containing the same concentrations of nitrate and sulfate (Fig. 9). An increase in the current density from $-1.6 \mathrm{~V}$ was observed for the two solutions, and the current density of nitrite was much higher than that of sulfate at any potential. The conductivity of sulfate solution $(13.48 \mathrm{mS} / \mathrm{cm})$ was higher than that of nitrate solution $(8.79 \mathrm{mS} / \mathrm{cm})$ at the same concentration. These results prove that nitrate reduction plays an important role during ECM and that it causes the sharp increase in $\mathrm{OH}^{-}$amount with increasing nitrate concentration (Reactions (12)-(14)). Furthermore, the peak current corresponding to the oxidation/reduction of $\mathrm{Sn}^{2+}$ to $\mathrm{Sn}^{4+}$ in the case of nitrate was much higher than that of sulfate. This observation may be attributed to the fact that nitrate is more aggressive than sulfate $[36,37]$.

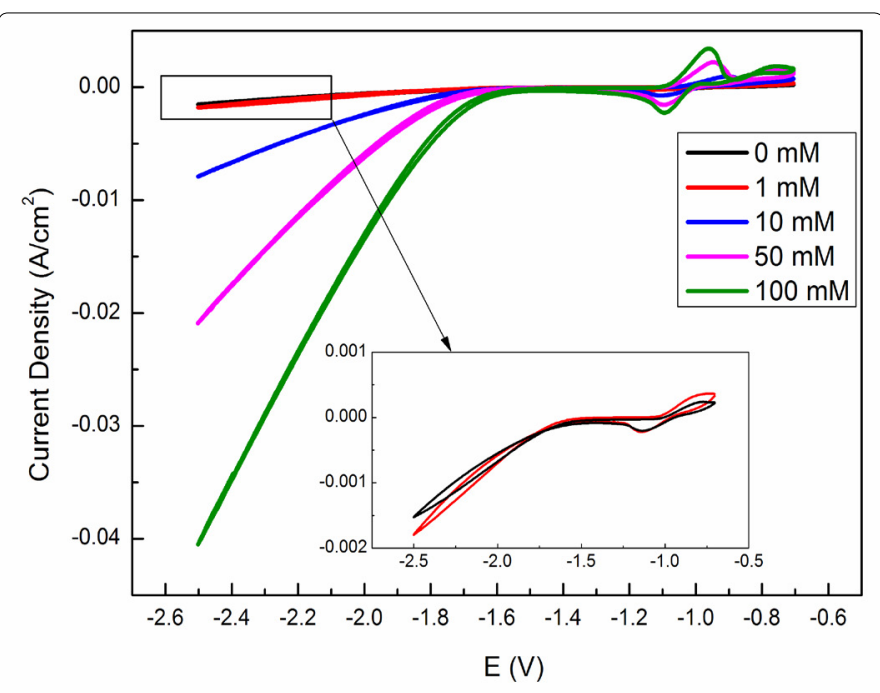

Fig. 8. Cyclic voltammograms for tin in solutions containing $1 \mathrm{mM}$ $\mathrm{Cl}$ - and varied concentrations of nitrate $(0 \mathrm{mM}, 1 \mathrm{mM}, 10 \mathrm{mM}, 50$ $\mathrm{mM}, 100 \mathrm{mM})$.

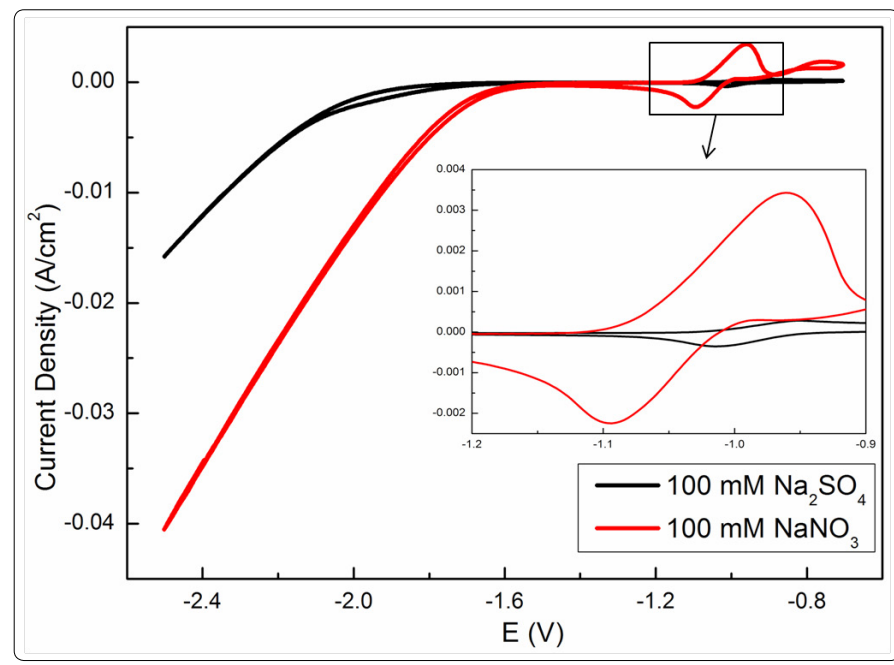

Fig. 9. Cyclic voltammograms for tin in solutions containing $1 \mathrm{mM}$ $\mathrm{Cl}$ - and same concentration of nitrate and sulfate .

\section{Effect of nitrate concentration on the ECM of tin}

As aforementioned result of the mean time to short circuit as a function of nitrate concentration (Fig. 2), the effect of nitrate concentration on the ECM of tin is significant. Therefore, the ECM dependence of tin throughout the whole test nitrate concentration range was discussed.

At low nitrate concentration (1-5 mM) levels, the anodic dissolution and cathodic deposition were accelerated mainly because of the increment of ionic conductivity. The amount of bubbles and precipitates increased compared with the absence of nitrate. A loose precipitate layer occurred between the anode and the cathode (Figs. 3 and 4). However, the loose precipitate layer could not hinder the growth of dendrites effectively.

With the increase in nitrate concentration from $10 \mathrm{mM}$ to $50 \mathrm{mM}$, both the anodic and cathodic reactions were considerably promoted at the beginning of the ECM, which was demonstrated by the high current density and the increase of bubbles evacuating from the cathode. A large amount of precipitates formed between the anode and the cathode with 
increasing $\mathrm{OH}^{-}$and $\mathrm{Sn}^{4+}$ concentrations. However, under this condition, dissolution of precipitates still cannot proceed because a higher $\mathrm{pH}$ is required. The precipitates gradually accumulated to form a thick precipitate layer. Fig. 10a shows the 3D micrograph of the electrode system during the ECM in a $200 \mu \mathrm{m}$-thick electrolyte layer containing $50 \mathrm{mM}$ nitrate ion and $1 \mathrm{mM} \mathrm{Cl}$ at $5 \mathrm{~V}$ for $1617 \mathrm{~s}$. The accumulated precipitates with a height of $625 \mu \mathrm{m}$ formed on the anode side and served as a wall-like barrier to impede the migration of ions. However, the accumulation of $\mathrm{OH}^{-}$produced by the cathodic reactions caused $\mathrm{Sn}(\mathrm{OH})_{4}$ to disproportionate into $\left[\mathrm{Sn}(\mathrm{OH})_{6}\right]^{2-}$ (Reaction (11)) and dendrites to grow.

When the nitrate concentration was further increased (100-200 mM), a wall-like barrier also formed on the anode side (Fig. 10b) and hindered the migration of ions. However, sufficient $\mathrm{OH}^{-}$could be produced rapidly at the cathode because of the extensive reduction of nitrate. In this case, $\mathrm{Sn}(\mathrm{OH})_{4}$ dissolved to form $\left[\mathrm{Sn}(\mathrm{OH})_{6}\right]^{2-}$, and the hindering effect of the precipitate layer was weakened. Thus, dendrites grew quickly toward the anode direction.
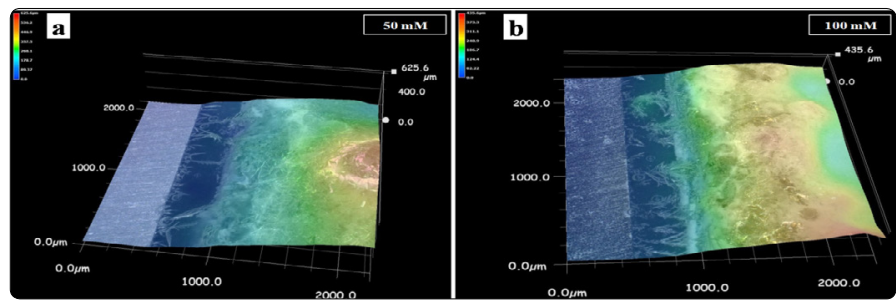

Fig. 10. 3D micrographs of precipitates formed during the ECM of

tin in $200-\mu \mathrm{m}$-thick electrolyte layer containing $1 \mathrm{mM} \mathrm{Cl}-$ and varied nitrate concentrations at $5 \mathrm{~V}$ for different time intervals: (a) $50 \mathrm{mM}, 1617 \mathrm{~s}$; (b) $100 \mathrm{mM}, 81 \mathrm{~s}$ (anode is on the right and cathode is on the left).

\section{Conclusion}

This study investigated the effect of nitrate concentration on the ECM of tin in TELs. At low nitrate concentrations (1-5 $\mathrm{mM}$ ), the rate of dendrite growth did not change considerably. However, at intermediate nitrate concentrations (10-50 mM), dendrites grew at the slowest rate resulting from the accumulation of precipitates that acted as a wall-like barrier to hinder the migration of ions. At a high nitrate concentration $(100 \mathrm{mM})$, the intensive cathodic reactions produced large amounts of $\mathrm{OH}^{-}$, which caused the dissolution of the precipitate layer and the fast growth of dendrites from the cathode to the anode.

\section{Acknowledgements}

The authors thank the National Natural Science Foundation of China (Nos. 51571098) for their financial support and the Analysis Support of the Analytical and Testing Center, Huazhong University of Science and Technology.

Conflicts of Interest: The author reports no conflict of interest.

\section{References}

1. Daniel $M$, Jellesen MS, Møller $P$, Ambat R. On the electrochemical migration mechanism of tin in electronics. Corros Sci. 2011;53:33663379. http://dx.doi.org/10.1016/j.corsci.2011.06.015
2. Jung JY, Lee SB, Joo YC, Lee HY, Park YB. Anodic dissolution characteristics and electrochemical migration lifetimes of $\mathrm{Sn}$ solder in $\mathrm{NaCl}$ and $\mathrm{Na} 2$ SO 4 solutions. Microelectron Eng. 2008;85:1597-1602. http://dx.doi. org/10.1016/j.mee.2008.03.015

3. Zhou $Y$, Huo $Y$. The comparison of electrochemical migration mechanism between electroless silver plating and silver electroplating. J. Mater. Sci. - Mater. Electron. 2016; 27:931-941. doi: 10.1007/s10854-015-3836-z

4. Noh BI, Jung SB. Characteristics of environmental factor for electrochemical migration on printed circuit board. J. Mater. Sci. - Mater. Electron. 2008;19:952-956. doi: 10.1007/s10854-007-9421-3

5. Lopez BG,Valdez SB, Zlatev KR, Flores PJ, Carrillo BM, Schorr WM Corrosion of metals at indoor conditions in the electronics manufacturing industry. Anti-Corros. Methods Mater. 2007; 54:354-359. http://dx.doi. org/10.1108/00035590710833510

6. Shnawah DA, Sabri MFM, Badruddin IA. A review on thermal cycling and drop impact reliability of SAC solder joint in portable electronic products. Microelectron. Reliab. 2012;52:90-99. http://dx.doi.org/10.1016/j. microrel.2011.07.093

7. Medgyes $B$, Illés $B$, Berényi R, Harsányi G. In situ optical inspection of electrochemical migration during THB tests. J. Mater. Sci. - Mater. Electron. 2011;22:694-700. doi: 10.1007/s10854-010-0198-4

8. Lee SB, Yoo YR, Jung JY, Park YB, Kim YS, Joo YC. Electrochemical migration characteristics of eutectic SnPb solder alloy in printed circuit board. Thin Solid Films. 2006;504:294-297. http://dx.doi.org/10.1016/j. tsf.2005.09.022

9. Medgyes $B$, Illés $B$, Harsányi $G$. Electrochemical migration behaviour of $\mathrm{Cu}, \mathrm{Sn}, \mathrm{Ag}$ and Sn63/Pb37. J. Mater. Sci. - Mater. Electron. 2012;23:551556. doi: 10.1007/s10854-011-0435-5

10. Yu DQ, Jillek W, Schmitt E. Electrochemical migration of lead free solder joints. J. Mater. Sci. - Mater. Electron. 2006;17:229-241. doi: 10.1007/ s10854-006-6765-z

11. Noh $\mathrm{BI}$, Jung $\mathrm{SB}$. Behaviour of electrochemical migration with solder alloys on printed circuit boards (PCBs). Circuit World. 2008;34:8-13. http://dx.doi.org/10.1108/03056120810918060

12. He $\mathrm{X}$, Azarian MH, Pecht MG. Evaluation of electrochemical migration on printed circuit boards with lead-free and tin-lead solder. J. Electron. Mater. 2011;40:1921-1936. doi: 10.1007/s11664-011-1672-3

13. Noh BI, Lee JB, Jung SB. Effect of surface finish material on printed circuit board for electrochemical migration. Microelectron. Reliab. 2008;48:652656. http://dx.doi.org/10.1016/j.microrel.2007.09.006

14. Minzari $D$, Jellesen MS, Møller $P$, Wahlberg $P$, Ambat R. Electrochemical migration on electronic chip resistors in chloride environments. IEEE Trans. Device Mater. Reliab. 2009;9:392-402. doi: 10.1109/TDMR.2009.2022631

15. Verdingovas $V$, Jellesen MS, Ambat R. Influence of sodium chloride and weak organic acids (flux residues) on electrochemical migration of tin on surface mount chip components. Corrosion Engineering, Science and Technology. 2013;48:426-435. doi: http://dx.doi.org/10.1179/174327821 $3 Y .0000000078$

16. Zhong X, Guo X, Qiu Y, Chen Z, Zhang G. In Situ Study the Electrochemical Migration of Tin under Unipolar Square Wave Electric Field. J. Electrochem. Soc. 2013;160: D495-D500. doi: 10.1149/2.014311jes

17. Verdingovas $V$, Jellesen MS, Ambat R. Effect of pulsed voltage on electrochemical migration of tin in electronics. $J$ Mater Scie: Mater in Electron. 2015;26:7997-8007. doi: 10.1007/s10854-015-3454-9

18. Dominkovics $C$, Harsányi G. Fractal description of dendrite growth during electrochemical migration. Period Polytec Elec Eng. 2008;52:1319. doi: $10.3311 /$ pp.ee.2008-1-2.02

19. Dominkovics C, Harsányi G. Fractal description of dendrite growth during electrochemical migration. Microelectron. Reliab. 2008;48:16281634. doi: http://dx.doi.org/10.1016/j.microrel.2008.06.010

20. Minzari D, Grumsen FB, Jellesen MS, Møller P, Ambat R. Electrochemical migration of tin in electronics and microstructure of the dendrites. Corros Sci. 2011;53:1659-1669. doi: http://dx.doi.org/10.1016/j. corsci.2011.01.009 
21. Zhong X, Zhang G, Qiu Y, Chen Z, Zou W, Guo X. In situ study the dependence of electrochemical migration of tin on chloride. Electrochem. Commun. 2013;27:63-68. http://dx.doi.org/10.1016/j. elecom.2012.11.010

22. Zhong X, Zhang G, Qiu Y, Chen Z, Guo X. Electrochemical migration of tin in thin electrolyte layer containing chloride ions. Corros Sci. 2013;74:71-82. http://dx.doi.org/10.1016/j.corsci.2013.04.015

23. Lacasa $E$, Canizares $P$, Llanos J, Rodrigo MA. Effect of the cathode material on the removal of nitrates by electrolysis in non-chloride media. J hazard mater. 2012;213:478-484. http://dx.doi.org/10.1016/j. jhazmat.2012.02.034

24. Liu GD, Wu WL, Zhang J. Regional differentiation of non-point source pollution of agriculture-derived nitrate nitrogen in groundwater in northern China. Agr ecosys environ. 2005;107:211-220. http://dx.doi. org/10.1016/j.agee.2004.11.010

25. Wu S, Wang B, Yang D, Wei H, Li H, Pan L, et al. Ambient particulate air pollution and circulating antioxidant enzymes: A repeated-measure study in healthy adults in Beijing, China. Environ. Pollut. 2016;208:16-24. doi: 10.1016/j.envpol.2015.06.002

26. Camargo JA, Alonso A. Ecological and toxicological effects of inorganic nitrogen pollution in aquatic ecosystems: a global assessment. Environ. Int. 2006;32:831-849. doi: 10.1016/j.envint.2006.05.002

27. Medgyes B, Zhong X, Harsányi G. The effect of chloride ion concentration on electrochemical migration of copper. J Mater Scie: Mater in Electron. 2015;26:2010-2015. doi: 10.1007/s10854-014-2640-5

28. Katsounaros I, Ipsakis D, Polatides C, Kyriacou G. Efficient electrochemical reduction of nitrate to nitrogen on tin cathode at very high cathodic potentials. Electrochim. Acta. 2006;52:1329-1338. doi: http://dx.doi. org/10.1016/j.electacta.2006.07.034
29. Ambrosioni B, Barthelemy A, Bejan D, Bunce NJ. Electrochemical reduction of aqueous nitrate ion at tin cathodes. Can. J. Chem 2013;92:228-233. doi: 10.1139/cjc-2013-0406

30. Katsounaros I, Kyriacou G. Influence of nitrate concentration on its electrochemical reduction on tin cathode: Identification of reaction intermediates. Electrochim. Acta. 2008;53:5477-5484. doi: http://dx.doi. org/10.1016/j.electacta.2008.03.018

31. Badea GE. Electrocatalytic reduction of nitrate on copper electrode in alkaline solution. Electrochim. Acta. 2009;54:996-1001. doi: http://dx.doi. org/10.1016/j.electacta.2008.08.003

32. De D, Kalu EE, Tarjan PP, Englehardt JD. Kinetic Studies of the Electrochemical Treatment of Nitrate and Nitrite Ions on Iridium Modified Carbon Fiber Electrodes. Chem eng technol. 2004;27:56-64. doi: $10.1002 /$ ceat.200401832

33. Bockris JM, Kim J. Electrochemical treatment of low-level nuclear wastes. J. Appl. Electrochem 27 (1997) 623-634. doi: 10.1023/A:1018419316870

34. Tucker PM, Waite MJ, Hayden BE. Electrocatalytic reduction of nitrate on activated rhodium electrode surfaces. J. Appl. Electrochem. 2004;34:781796. doi: 10.1023/B:JACH.0000035607.19248.b6

35. Refaey S, El Rehim SA. Inhibition of chloride pitting corrosion of tin in alkaline and near neutral medium by some inorganic anions. Electrochim. Acta.1997;42:667-674. doi: 10.1016/S0013-4686(96)00212-5

36. Rehim SA, Sayyah S, El Deeb M. Corrosion of tin in citric acid solution and the effect of some inorganic anions. Mater. Chem. Phys. 2003;80:696703. doi: http://dx.doi.org/10.1016/S0254-0584(03)00128-7

37. Sasaki T, Kanagawa R, Ohtsuka T, Miura K. Corrosion products of tin in humid air containing sulfur dioxide and nitrogen dioxide at room temperature. Corros Sci. 2003;45:847-854. doi: http://dx.doi.org/10.1016/ S0010-938X(02)00151-8 